\title{
Airborne pollen in Funchal city, (Madeira Island, Portugal) - First pollinic calendar and allergic risk assessment
}

\author{
Irene Câmara Camacho' \\ ${ }^{1}$ Life Science Competence Centre, Madeira University, Portugal \\ Camacho IC. Airborne pollen in Funchal city, (Madeira Island, Portugal) - First pollinic calendar and allergic risk assessment. Ann Agric Environ \\ Med. 2015; 22(4): 608-613. doi: 10.5604/12321966.1185762
}

\begin{abstract}
Introduction. Nowadays, pollen calendars are useful tools for clinical guidance intended for allergy sufferers, because they can be used to prevent and manage allergic respiratory diseases, thus improving the quality of life.

Objectives. An aeropalinological study was performed in the city of Funchal with the purpose of establishing a pollen calendar and determining allergic risk, based on a seven year study (2003-2009).

Material and Methods. The airborne pollen monitoring was carried out with a Hirst type volumetric spore trap, following well-established guidelines.

Results. The mean annual pollen index was 1,635.09 and comprised 42 different pollen types. Airborne pollen levels were higher between March - June, accounting for $57.9 \%$ of the annual counts. Arboreal pollen grains (52.72\%) prevailed in the atmosphere together with herbs and grasses (44.64\%), while fern spores (2.29\%) and unidentified pollen (0.35\%) were scarce. The main pollen types were Urticaceae (20.64\%), Poaceae (16.02\%), Cupressaceae (13.61\%), Pinaceae (9.07\%), Myrtaceae (5.93\%) and Ericaceae (5.02\%). The pollen calendar comprised a total of 14 taxa and is similar to Mediterranean regions, with the exception of Olea europaea, Quercus sp., Betula sp. and Alnus sp. pollen types which are rare or absent. The main pollen season of major pollen taxa is significantly longer in Funchal (on average 239 days) than other European sites, especially for Urticaceae and Poaceae, but the pollen peaks were substantially lower.

Conclusions. The pollen calendar for Funchal is the first ever created for Madeira region. Taking into account the low pollen index and number of allergy-risk days recorded (39 days in 7 years), the air quality of Funchal can be considered good.
\end{abstract}

\section{Key words}

Aerobiology, Pollen calendar, Allergy risk, Portugal

\section{INTRODUCTION}

The origin, transport and deposition of biological particles in the atmosphere, including pollen and fungal spores, have been increasingly studied due to the known relationship with public health. Earlier investigations regarding the effects of these particles on human health showed a positive correlation between atmospheric pollen counts and allergic symptomatology [1]. In vitro studies, such as the secretion profile of cytokines in patients with pollinosis, determined the existence of increased disease activity during the pollen season [2].

Pollen and spores are airborne entities fulfilling their reproductive mission which, together with bacteria and viruses, represent an important component of atmospheric aerosols. Once in the atmosphere, the airborne particles are subject to the same laws that conduct the dispersion and sedimentation of particles in general [3]. Pollen grains are considered a major source of outdoor aeroallergens and are listed as one of the most abundant foreign elements in the air, being directly involved in diseases such as asthma, pollen allergy [4, 5], and, to some extent, infectious problems [6]. These pollen grains contain allergens that trigger the allergic inflammatory response, via mast cell activation in the human

Address for correspondence: Irene Câmara Camacho, Madeira University, Life Science Competence Centre, Campus Universitário da Penteada, 9000-390 Funchal, Portugal

E-mail: camire@uma.pt

Received: 03 December 2013; accepted: 18 November 2014 mucosa of the target organs, giving rise to a systemic reaction [7]. Pollen allergen sensitization may occur in isolation or associated with other perennial allergens, such as those derived from fungal spores, dust mites, cockroaches and other animals [8]. Multiple sensitization might increase or mask the clinical symptomatology of patients susceptible to pollen allergens. Also, allergy can be triggered in atopic individuals by exposure to large amounts of pollen during an extended period of time.

Monitoring air pollen content has become a common practice worldwide, and most of the aerobiological research focused on airborne pollen content and publishing pollen calendars for the diagnosis and prevention of pollinosis [9]. During the flowering season, daily results and pollen forecasts are often a part of weather reports. Knowledge of such data allows the adoption of measures to prevent exposure to high levels of pollen allergens during peak periods, and also a better interpretation of respiratory problems in allergic patients. For that purpose, the Portuguese Aerobiology Network was established in 2002, based on the Hirst methodology which is recommended by the International Association of Aerobiology (IAA) and integrated into the European Aeroallergen Network (EAN). The national network has been increasing the coverage throughout the country, monitoring the pollen and fungal spores of allergenic interest and providing pollen forecasts on websites and social media. So far, data show that the most prevalent pollen types found in the atmosphere of Portugal belong to Gramineae, Oleaceae, Fagaceae, Pinaceae, Cupressaceae, Platanaceae and Urticaceae families. 
Climatic changes are ongoing and changes in distribution, quantity and quality of pollen are occurring, together with a shift in the timing and lengthening of the pollen season [10], rendering it vital to obtain data in order to monitor those changes and assess the effects on public health. Long-term aerobiological surveys reveal an increasing in the yearly airborne pollen for many taxa in Europe, which are more prominent in urban areas [11]. Such aerobiological datasets evidence phenological and biogeographic shifts, both on the regional and continental scale, together with an increase in pollen allergenicity [12].

The scenario of the presented work is the city of Funchal, the capital of Madeira Island, one of the most important tourist regions of Portugal. Madeira's natural environment is its strongest asset in attracting tourists - more than $1,010,000$ in 2005 [13].

\section{OBJECTIVES}

The aim of this study is to determine the atmospheric pollen content of this region, on a seven year basis, in order to establish a pollen calendar for the town of Funchal. The analysis assesses the city's atmospheric pollen with the aim of informing citizens and tourists about the atmospheric pollen content, especially the allergenic pollen content and associated risk. This is essential for reducing the exposure of allergic patients to pollen during peak periods, and enable the adoption of preventive measures when planning outdoor activities.

\section{MATERIALS AND METHOD}

\section{Geomorphology}

The city of Funchal $\left(32^{\circ} 39^{\prime} \mathrm{N}, 16^{\circ} 55^{\prime} \mathrm{W}\right)$ (Fig. 1) is the most populous insular city in Portugal and the capital of the Madeira Archipelago, located in the Atlantic Ocean, southwest of mainland Portugal. Madeira Island has a total area of $737 \mathrm{~km}^{2}$ and a population of around 240,000 people. Due to its volcanic origin, the island is very mountainous, with a central mountain range about 1,200 $\mathrm{m}$ above sea level.

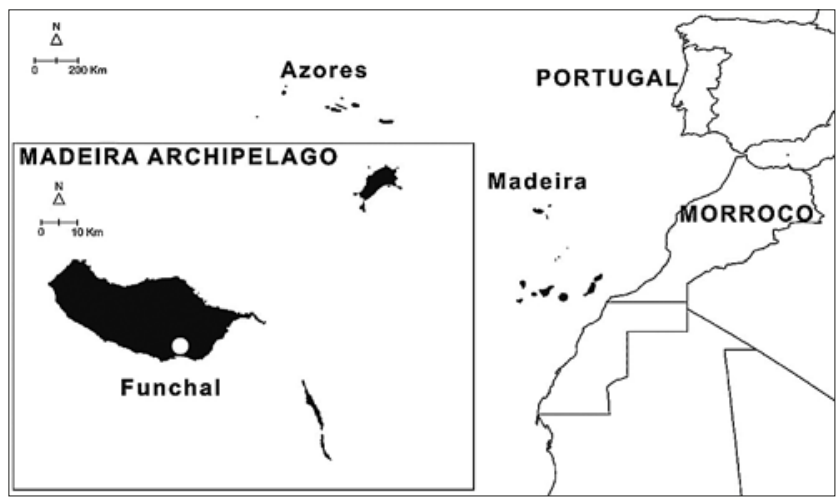

Figure 1. Location of Madeira archipelago and Funchal city

\section{Climate and vegetation.}

Madeira island presents a temperate hyperoceanic sub-Mediterranean bioclimate, with a Mediterranean pluviseasonal oceanic bioclimate on the south coast, with Funchal in particular lying within the thermo-subMediterranean and thermo-Mediterranean thermoclimatic belts [14]. The island has mild temperatures all year round (average temperature $18.7^{\circ} \mathrm{C}$ ), ranging from $15.9^{\circ} \mathrm{C}$ in February up to $22.3^{\circ} \mathrm{C}$ in August, with relative humidity of $55-75 \%$ and an annual rainfall of between $500-1,000 \mathrm{~mm}$ [15]. During the winter, the predominant wind direction is from the South-West quadrant, whereas in the summer the wind originates essentially from the North quadrant [16].

About two-thirds of the island is a natural park, which includes the Laurel forest, one of the best preserved evergreen forests in Macaronesia and declared a UNESCO world heritage site. The area surrounding the city is dominated by exotic species from the genera Acacia, Eucalyptus and Pinus. The parks and gardens of the city include a wide variety of exotic plants from around the world, e.g. Cupressaceae, Palmae, Casuarina species and tree ferns. In urban development areas there are patches of land used for agricultural purposes, mostly by Musa acuminata and Vitis vinifera.

\section{Airborne pollen monitoring}

The airborne pollen monitoring was performed with a Burkard Seven Day Volumetric Spore-trap ${ }^{\circledR}$ (Burkard Manufacturing Co. Ltd., UK), a Hirst type volumetric trap, during a 7-year period (2003-2009), following the guidelines of the IAA and the recommendations proposed by the Spanish Aerobiology Network [17]. The Burkard trap was placed at the roof of Dr. João de Almada Hospital in Funchal, $10 \mathrm{~m}$ above ground. Identification and counting of pollen grains was performed with a light microscope $(40 \times)$, based on 4 longitudinal transects along the slides.

\section{Data analysis}

Pollen concentration was calculated and expressed as the number of pollen grains per cubic meter of air $\left(\mathrm{p} / \mathrm{m}^{3}\right)$. The annual sum of daily airborne pollen concentrations was expressed as a Pollen Index (PI). In order to determine the airborne permanence of the most abundant pollen types, the Main Pollen Season (MPS), which includes 95\% of the seasonal total pollen count, was calculated. The pollen calendar was developed according to Spieksma's model [18]. The daily mean counts were calculated according to Stix and Ferretti [19]. Each 10-day mean corresponds to an exponential frequency class: Class 1 (1-2 pollen grains $/ \mathrm{m}^{3} /$ day) and Class 2 (3-5 pollen grains $/ \mathrm{m}^{3} /$ day). In the pollen calendar, the different taxa were ordered chronologically and only the taxa that showed a minimum 10 -day mean $\geq 1$ $\mathrm{p} / \mathrm{m}^{3}$ of air were included. A "Total” category was created and includes all taxa. The allergic risk for the most prevalent pollen types was estimated according to Galán et al [17]. The allergenic levels considered were: "moderate risk" - 25-50 p/ $\mathrm{m}^{3} /$ day for herbaceous taxa and $50-100 \mathrm{p} / \mathrm{m}^{3} /$ day for arboreal taxa; and "high risk" - > $50 \mathrm{p} / \mathrm{m}^{3} /$ day and $>100 \mathrm{p} / \mathrm{m}^{3} /$ day for herbaceous and arboreal taxa, respectively. The Biological Air Quality for the city was determined according to Galán et al [17].

\section{RESULTS}

The mean annual pollen index for Funchal determined during the study period (2003-2009) was 1,635.09, with the highest value $(4,747.6)$ recorded in 2009 and the lowest in 
2004 (450.9), along with a noticeable increase of the pollen levels over the years. The highest daily pollen peak was registered in 2009 by Cupressaceae and Polygonaceae, both with $64.26 \mathrm{p} / \mathrm{m}^{3}$ on 19 March and 3 April, respectively.

A marked seasonal variation in airborne pollen concentrations was detected, occurring in 2 annual peaks: the first and highest peak appearing during Spring - March June, and accounting for $57.9 \%$ of the annual pollen records, and a second smaller peak in October and November $(16.9 \%$ annual pollen). The month with the lowest pollen count was September (2.7\% annual pollen). During the first peak period there were 2 distinct main contributors: the initial was the arboreal pollen in March and April (monthly average $178.88 \mathrm{p} / \mathrm{m}^{3}$ ) and the second were herbs and grasses pollen in May and June, although in lower levels $\left(103.37 \mathrm{p} / \mathrm{m}^{3}\right)$. In the second peak period, the main contributors were the herbs and grasses $\left(79.48 \mathrm{p} / \mathrm{m}^{3}\right)$, almost 1.5 -fold the arboreal contribution $\left(54.78 \mathrm{p} / \mathrm{m}^{3}\right)$. Globally, arboreal pollen counts $(52.72 \%)$ were higher than herbs and grasses (44.64\%), with fern spores (2.29\%) and unidentified pollen grains (0.35\%) showing little predominance (Tab. 1).

During the 7-year sampling period, 42 different pollen types from 36 families were identified (Tab. 1). The most abundant pollen types were Urticaceae, accounting for $20.64 \%$ of the total pollen, followed by Poaceae $(16.02 \%)$, Cupressaceae (13.61\%), Pinaceae (9.07\%), Myrtaceae (5.93\%) and Ericaceae (5.02\%).

The main pollen season (MPS) of the 12 most abundant taxa, which account for $80.4 \%$ of all analysed pollen, lasted an average of 239 days (Tab. 2). The longest MPS registered for trees were of Myrtaceae, Cupressaceae and Pinaceae (average 315 days) while the remaining trees had an average MPS of 191 days. The herbs and grasses had an average MPS of 243 days, with Urticaceae and Poaceae showing longer MPS than the remaining herbs.
The allergic risk thresholds were exceeded on 39 days throughout the 7-year study period, occurring solely between $2006-2009$, and by 2 arboreal taxa and all 4 herbaceous taxa (Tab. 2). The 2 most abundant pollen types, Urticaceae and Poaceae, also correspond to the pollen with the highest risk of allergenicity and the number of days in which their concentration reached moderate or high risk levels to trigger allergic symptoms among the population of Funchal, and lasted a total of 31 days during the 7-year study. Cupressaceae, Casuarinaceae and Plantaginaceae each attained a moderately allergenic risk, once in 2009, and Polygonaceae also attained high allergenic risk once, also in 2009. From the total period accountingfor critical levels of allergens, $62 \%$ of these days were due to Urticaceae pollen.

A total of 14 pollen types met the requirements to be represented in the pollen calendar (Fig.2). Urticaceae and Poaceae, besides being the 2 most abundant pollen types in the atmosphere, also had the longest pollen seasons, whereas the remaining taxa had shorter pollen seasons, mostly from early spring until late summer. Globally, the pollen levels did not exceed Class 1, with the exception of Urticaceae, Cupressaceae and Casuarinaceae in March and April, and Poaceae in late June, all of which reached Class 2. During April, the greatest diversity of pollen types is observed with 10 out of 14 present in the atmosphere.

In January and February, only class 1 concentrations of Cupressaceae, Urticaceae and Pinaceae pollen were registered in the atmosphere. In mid-March, Cupressaceae reached its class 2 peak concentration which lasted until mid-April, while other taxa appeared in March and reached class 1, namely Fabaceae, Myrtaceae and Betulaceae. In April, other pollen types also started to appear, such as Ericaceae, Poaceae, Palmae, Polygonaceae in class 1 concentrations, and Casuarinaceae showed a class 2 peak in mid-April, as did Urticaceae in early April. During May and June, Urticaceae,

Table 1. Sum of Pollen Index 2003-2009 for all pollen taxa detected in Funchal

\begin{tabular}{|c|c|c|c|c|c|}
\hline Arboreal pollen & 7 year total PI & $\%$ & Non-arboreal pollen (Herbs and grasses) & 7 year total $\mathrm{PI}$ & $\%$ \\
\hline Cupressaceae (Cupressus) & $1,557.22$ & 13.61 & Urticaceae (Parietaria, Urtica) & $2,362.48$ & 20.64 \\
\hline Pinaceae (Pinus) & $1,037.88$ & 9.07 & Poaceae & $1,833.30$ & 16.02 \\
\hline Myrtaceae (Eucalyptus) & 678.24 & 5.93 & Plantaginaceae (Plantago) & 253.32 & 2.21 \\
\hline Ericaceae & 574.74 & 5.02 & Polygonaceae (Rumex) & 252.70 & 2.21 \\
\hline Fabaceae (Acacia, Mimosa) & 435.16 & 3.80 & Asteraceae (Artemisia, Taraxacum) & 192.78 & 1.68 \\
\hline Platanaceae (Platanus) & 297.00 & 2.59 & Liliaceae (Lilium) & 18.36 & 0.16 \\
\hline Casuarinaceae (Casuarina) & 279.86 & 2.45 & Rosaceae & 16.74 & 0.15 \\
\hline Fabaceae (Robinia) & 177.03 & 1.55 & Apiaceae & 9.18 & 0.08 \\
\hline Fagaceae (Castanea, Quercus) & 161.98 & 1.41 & Nyctaginaceae & 7.02 & 0.06 \\
\hline Salicaceae (Salix) & 130.68 & 1.14 & Onagraceae (Fuchsia) & 4.32 & 0.04 \\
\hline Palmae & 96.12 & 0.84 & Passifloraceae & 1.62 & 0.01 \\
\hline Boraginaceae (Echium) & 30.24 & 0.26 & Lamiaceae (Lavandula) & 0.54 & 0.00 \\
\hline Ginkgoaceae (Ginkgo) & 24.84 & 0.22 & Caryophyllaceae (Dianthus) & 0.54 & 0.00 \\
\hline Myricaceae (Myrica) & 21.06 & 0.18 & Strelitziaceae (Strelitzia) & 0.54 & 0.00 \\
\hline Euphorbiaceae (Euphorbia, Ricinus) & 17.28 & 0.15 & Fern Spores (Adiantum, Pteris, trilete spores) & 305.02 & 2.66 \\
\hline Ulmaceae & 5.40 & 0.05 & Unknown & 41.04 & 0.36 \\
\hline Solanaceae (Datura) & 4.32 & 0.04 & TOTAL & $11,445.61$ & 100 \\
\hline Aceraceae & 2.16 & 0.02 & & & \\
\hline
\end{tabular}


Table 2. Main Pollen Season characteristics and associated allergic risk for the 12 most prevalent taxa in Funchal

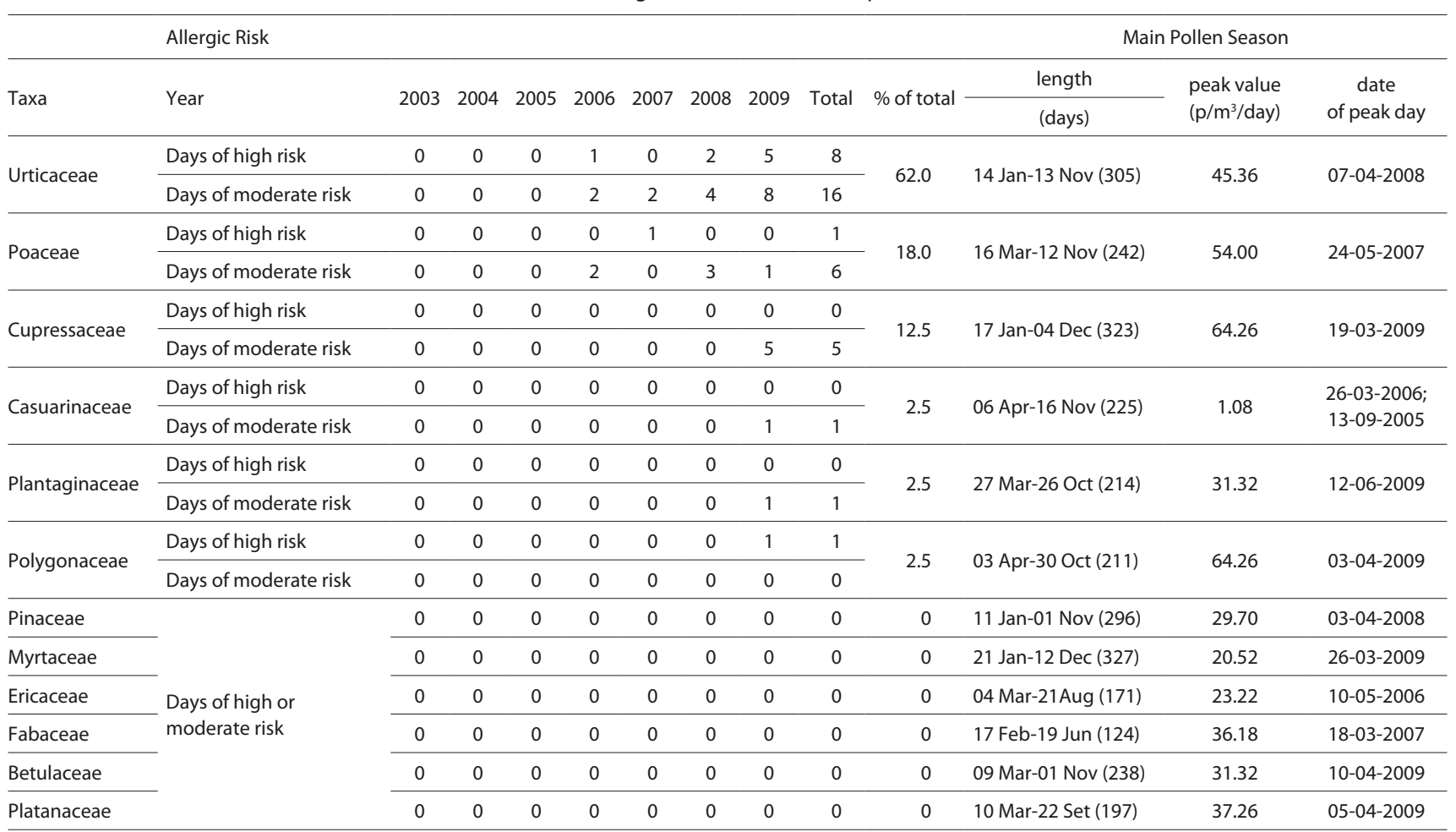

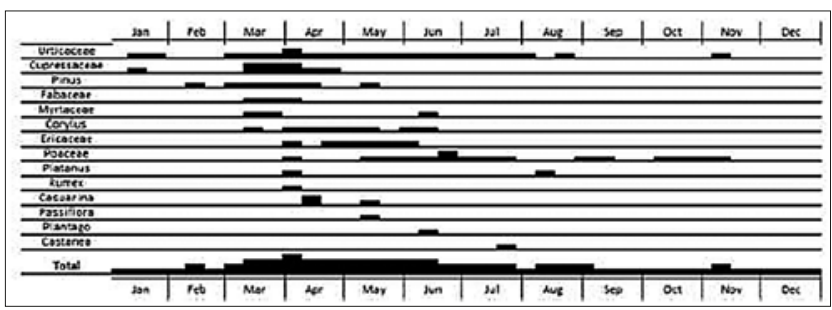

Figure 2. Pollen calendar for Funchal city (2003-2009)

Betulaceae, Ericaceae and Poaceae pollen persisted in class 1 levels, with the latter reaching a class 2 peak in late June. During this same period, Pinaceae, Casuarinaceae and Platanaceae appeared briefly in mid-May and Myrtaceae and Plantaginaceae in mid-June. Throughout the remainder of the year, Urticaceae and Poaceae pollen maintained their non-continuous presence in class 1 levels until midNovember, whereas the remaining taxa disappeared from the atmosphere, with exceptions of the pollen of summerflowering Fagaceae (Castanea) in mid-July and Palmae in mid-August, both at class 1 levels.

\section{DISCUSSION}

The city of Funchal has a peculiar aerobiological composition due to geo-climatic conditions that favour the adaptation and flowering of several native and allochthonous plants throughout the year. The pollinic spectrum reflects the flora of the town and is dominated by the ruderal grasses Poaceae and Urticaceae, a common component of the urban landscape, by ornamental plants (Cupressaceae, Casuarinaceae) and by wild growing plants found in the city's northern boundaries (Ericaceae, Myrtaceae and Pinaceae).
The pollen composition and dominance observed in the atmosphere of Funchal is similar to that found in other regions of Portugal [20] and can be considered as having Mediterranean characteristics, with the main difference that Olea europaea and Quercus sp. pollen are much less present. Also, the occurrence of Artemisia sp. pollen, an important taxon in eastern Europe, and of Betulaceae (Betula sp. and Alnus sp.) and Fraxinus sp. pollen, frequent in the northern and central Europe, is practically non-existent.

The mean PI detected in Funchal $(1,635.09)$ is lower than other bioclimatically-related areas, or even areas with geographical affinities to Madeira region, such as the Canary Islands (PI=6,309) [21] and Palma de Mallorca (PI $=20,027$ ) in Spain [22], and Ponta Delgada in Portugal (PI $=2,436$ ) (unpublished data). Compared with the Portuguese mainland, the PI of Funchal is substantially lower, either with the lowest mainland PI found in Coimbra $(7,841.5)$ or with the highest found in Évora $(54,366.4)$ [20]. The lower PI found in Funchal can be partially explained by the prevailing winds from the sea (SW) during most of the year, as shown by various authors at coastal sites [3]. Also, insular and coastal stations tend to have lower pollen concentrations than those on the mainland [23] due to the lower possibility of pollen resuspension and less land mass with plant coverage.

The trend of increase of PI throughout the years observed in Funchal during the study period is in accordance with reports from other regions, a fact commonly attributed, among others, to climatic changes [10,24].

Regarding the seasonal dynamics, the highest pollen concentration and diversity was detected during late winter until the end of spring (March until June) [22], similar to that which occurs in mainland Portugal [20] although in much lower concentrations.

Compared with other European regions, the pollen calendar for Funchal shows fewer taxa and, as observed in other reports, 
a small number of pollen types accounting for most of the total count, e.g. Poaceae and Urticaceae [25]. The high prevalence of Urticaceae pollen derives from the widespread presence of Parietaria judaica and Urtica membranacea in urban and suburban areas of the city, the same as several species of Poaceae that bloom year-round and dominate herbaceous communities. Other dominant pollen types belong to arboreal plants, namely, Cupressaceae, Pinaceae and Myrtaceae, which derive mostly from woods located in the adjacent areas of the city. The prevalence of the Cupressaceae pollen type in Funchal is due to Cupressus sempervirens, C. lusitanica, C. macrocarpa, Chamaecyparis lawsoniana and Juniperus cedrus, currently used as ornamental plants in many gardens. Other main pollen sources comprise species of Betulaceae (Corylus avellana; C. maxima) and Platanaceae (Platanus $\mathrm{x}$ acerifolia) which are also common ornamental plants.

The pollen calendar for Funchal showed that Urticaceae and Poaceae have long pollen seasons while the remaining taxa have shorter ones. Urticaceae pollen is observed from early January until mid-summer, and Poaceae appears from spring until November, hence with overlapping pollen seasons. The main pollen season for both families is longer in Funchal (on average 274 days) than in other European sites, probably because of the good climatic conditions that favour the development of many kinds of plants [15], but the peak amounts were substantially lower. The pattern for the Urticaceae pollen peak period (March-April) and dwelling time in the atmosphere is similar to that observed in Italy [26] and Poland [27]. Concerning Poaceae, the pollen season was also longer compared with other European sites, with the highest concentrations in May and June, and with a continued presence in the atmosphere similar to most European cities [28,29].

Regarding the allergic risk during the study period, the risk by Urticaceae and Poaceae pollen was the most frequent but only lasted a few days per year, although the very long pollen season and plant abundance may affect allergysufferers. Nevertheless, the triggering of allergic symptoms depends on individual susceptibility to each allergen load and degree of exposure. Despite the absolute pollen prevalence for both pollen types being relatively low, the prevalence of sensitization to Poaceae and Urticaceae pollen among allergypatients in Madeira region is relatively high, at $47 \%$ and $65 \%$, respectively [30]. Grasses are important aeroallergens in Europe, being one of the most substantial aeroallergen in Portugal where sensitization to these pollens reaches $53.9 \%$ [31]. Cupressaceae reached a moderately allergenic level only during 5 days throughout the entire study, but due to the pollen season months and the prevalence of sensitization of around $40 \%$ in the population of Madeira[30], it should be considered as a potential cause of winter pollinosis in susceptible patients. Casuarinaceae, Plantaginaceae and Polygonaceae reached allergy risk levels only once during the entire study, so they should not be a threat to the population, especially if we take into considereation the fact that the prevalence of pollen-allergy sufferers sensitized to Plantago reaches only $11.4 \%$ in Portugal [31].

Considering that airborne pollen counts remained at low levels in the atmosphere of Funchal, particularly the main allergenic pollen types, and that the number of allergy-risk days were significantly lower than in other European cities, we can state that the Biological Air Quality in the city is good, according to the Galán et al [17] classification.

\section{CONCLUSIONS}

The pollen calendar for Funchal is the first to be created for Madeira region. It represents a useful tool for clinical guidance intended for allergy sufferers, either the local or foreign population, and can be used to prevent and manage allergic respiratory diseases, thus improving the quality of life. During the 7-year study period, the mean annual pollen index obtained in Funchal city was 1,635.09, which is lower than many other European cities. The pollen peak period was between March and June, accounting for 57.9\% of the annual pollen count, while the lowest counts were in September. The annual pollen count showed an uptrend over the years. Despite the high phytodiversity observed in Funchal, the main pollen contributors comprised a few taxa, like the herbaceous plants Urticaceae and Poaceae, followed by trees like Cupressaceae, Pinaceae and Myrtaceae. The pollen calendar included fewer taxa (14) than other European sites and had longer pollen seasons, mostly by Urticaceae and Poaceae. The pollinic spectrum is similar to Mediterranean regions, but Olea europaea and Quercus sp. are scarce and Betula sp. and Alnus sp. pollens are absent. The low number of allergy-risk days, together with the low pollen counts, allows us to conclude that the air quality in Funchal is good.

\section{Acknowledgments}

The author expresses his thanks to the Dr. João de Almada Hospital, Madeira University, and especially to the Portuguese Society of Allergology and Clinical Immunology for their help and financial support in this aerobiological study of Funchal. The author would also like to thank Roberto Pisa Camacho for his assistance in the statistical analysis and proof reading.

\section{REFERENCES}

1. Sibbald B, Strachan D. Epidemiology of rhinitis. In: Busse W, Holgate ST. Mechanisms in Asthma and Rhinitis: Implications for Diagnosis and Treatment. Oxford, Blackwell Scientific, 1994.p.32-43.

2. Todo-Bom A, Brandão R, Nunes C, Caeiro E, Leitão T, Oliveira JF, et al. Allergenic airborne pollen in Portugal 2002-2004. Rev Port Imunoalergologia. 2006; 14(1): 41-49.

3. Jones AM, Harrison RM. The Effects of Meteorological Factors on Atmospheric Bioaerosol Concentrations - A Review. Sci Total Environ. 2004; 326: 151-180.

4. Amjad L, Shafighi M. The Effect of Air Pollution on Chenopodium album L. pollen structure. J Agric Sci Technol. 2012; A2: 143-148.

5. Cariñanos P, Prieto JC, Galan C, Domínguez E. Solid suspended particles affecting the quality of air in urban environments. Bull Environ Contam Toxicol. 2001; 67: 385-391.

6. Oteros J, Galán C, Alcázar P, Domínguez-Vilches E. Quality control in bio-monitoring networks, Spanish Aerobiology Network. Sci Total Environ. 2013; 443: 559-565.

7. Kiotseridis H, Cilio CM, Bjermer L, Tunsäter A, Jacobsson H, Dahl A. Grass pollen allergy in children and adolescents symptoms, health related quality of life and the value of pollen prognosis. Clin Transl Allergy. 2013; 3: 19.

8. Taketomi EA, Sopelete MC, Moreira PFS, Vieira FAM. Pollen allergic disease: pollens and its major allergens. Rev Bras Otorrinolaringol. 2006; 72(4): 562-567.

9. D'Amato G, Liccardi G. The increasing trend of seasonal respiratory allergy in urban areas. Allergy. 2002; 57(71): 35-36.

10. Shea KM, Truckner RT, Weber RW, Peden DP. Climate change and allergic disease. J Allergy Clin Immunol. 2008; 122: 443-453.

11. Ziello C, Sparks TH, Estrella N, Belmonte J, Bergmann KC, Bucher E. et al. Changes to airborne pollen counts across Europe. PLoS ONE. 2012; 7(4): e34076. 
12. Ziska LH, Beggs PJ. Anthropogenic climate change and allergen exposure: The role of plant biology. J Allergy Clin Immunol. 2012; 129: 27-32.

13. Oliveira P, Pereira PT. Who values what in a tourism destination? The case of Madeira Island. Tourism Econ. 2008; 14(1): 155-168.

14. Rivas-Martínez S. Bioclimatic Map of Europe - Thermotypes Cartographic Service, University of Léon, Léon. 2001.

15. Quintal R. Quintas, Parques e Jardins do Funchal - Estudo fitogeográfico. Lisboa, Esfera do Caos Editores, 2007.

16. Santos FD, Valente MA, Miranda PMA, Aguiar A, Azevedo EB, Tomé $\mathrm{AR}$, et al. Climate change scenarios in the Azores and Madeira islands. World Resource Rev. 2004; 16(4): 473-491.

17. Galán C, Cariñanos P, Alcázar P, Dominguez E. Spanish Aerobiology Network (REA): Management and Quality Manual. Córdoba, Universidad de Córdoba, 2007.

18. Spieksma FThM. Regional european pollen. In: D'Amato G, Spieksma FThM, Bonini S. Allergenic Pollen and Pollinosis in Europe. Oxford, Blackwell, 1991.p.49-65

19. Stix E, Ferretti ML. Pollen calendars of three locations in Western Germany. In: Charpin J, Surynyach R, Frankland AW. Atlas European des Pollens Allergisants. Paris, Sandoz, 1974.p.85-94.

20. Caeiro E, Brandão R, Carmo S, Lopes L, Almeida MM, Gaspar A, et al. The Portuguese Aerobiology Network: Airborne pollen results (2002-2006). Rev Port Imunoalergologia. 2007; 15(3): 235-250.

21. Belmonte J, Cuevas E, Poza P, González R, Roure JM, Puigdemunt R, et al. Aerobiología y alergias respiratorias de Tenerife. Santa Cruz de Tenerife, Agencia Estatal de Meteorología (AEMET), 2010.
22. Boi M, Lloren L. Annual pollen spectrum in the air of Palma de Mallorca (Balearic Islands, Spain). Aerobiologia. 2013; 29(3): 385-397.

23. Belmonte J, Puigdemunt R, Cuevas E, Alonso S, González R, Poza P, et al. Eolo-PAT project: Aerobiology and respiratory allergies in Santa Cruz de Tenerife since 2004. Allergy. 2008; 63(88): 158-611.

24. Levetin E, Van de Water P. Changing Pollen Types/Concentrations/ Distribution in the United States: Fact or Fiction? Curr Allergy Asthma Rep. 2008; 8: 418-424.

25. Pérez-Badia R, Rapp A, Vaquero C, Fernández-González F. Aerobiological study in East-Central Iberian Peninsula: Pollen diversity and dynamics for major taxa. Ann Agric Environ Med. 2011; 18: 99-111.

26. Longo LR, Sauli MP, Ganis P. Aerobiology of Urticaceae pollen in Trieste (NE Italy). Aerobiologia. 2004; 20(1): 53-61.

27. Kasprzyk I, Harmata K, Myszkowska D, Stach A, Stepalska D. Diurnal variation of chosen airborne pollen at five sites in Poland. Aerobiologia. 2001; 17: 327-345.

28. Leuschner RM, Christen Jordan HP, Vonthein R. 30 years of studies of grass pollen in Basel (Switzerland). Aerobiologia. 2000; 16: 381-391.

29. Muñoz AF, Silva I, Tormo R. The relationships between Poaceae pollination levels and cereal yields. Aerobiologia. 2000; 16: 281-286.

30. Câmara R, Câmara I, Oliveira S, Carvalho MA, Borges F. Prevalência de Sensibilização a Pólens em Doentes com Rinite da Consulta de Imunoalergologia do C.H.F. Rev Port Imunoalergologia. 2001; 9(2): 176-180.

31. Loureiro G, Blanco B, São Braz MA, Pereira C. Reactividade cutânea a aeroalergénios numa população alérgica da Cova daBeira. Rev Port Imunoalergologia. 2003; 11: 107-116. 